\title{
The Relationship between Ownership Structure and Firm's Performance: An Empirical Evidence from Palestine
}

\author{
Nizar Dwaikat ${ }^{1} \&$ Abdelbaset Queiri ${ }^{1}$ \\ ${ }^{1}$ Graduate School of Management, Multimedia University, Malaysia \\ Correspondence: Abdelbaset Queiri, Graduate School of Management, Multimedia University, Persiaran \\ Multimedia,63000 Cyberjaya, Selangor, Malaysia. E-mail: basset11519@gmail.com
}

Received: September 23, 2014

Accepted: November 3, 2014

Online Published: November 22, 2014

doi:10.5539/ijbm.v9n12p49

URL: http://dx.doi.org/10.5539/ijbm.v9n12p49

\begin{abstract}
This study examines the relationship between the ownership structure and performance of 31 firms listed on the Palestine Stock Exchange (PS) during the period of 2008-2012. The results reveal that ownership concentration to be significantly negative related with performance of firms (Tobin's Q and ROA), while the insider ownership (executive management and directors of board) found to have significant positive relation with firm's performance (Tobin's Q and ROA). The findings supported the prediction of alignment hypothesis (aligning interests between manager and shareholders), and the results provided evidence for negative effect of ownership concentration which could be considered support for entrenchment hypothesis.
\end{abstract}

Keywords: ownership structures, Palestine, ownership concentration

\section{Introduction}

The forming of ownership structure differs among countries. Several of them are widely held, while others are in the hands of large stockholders. Generally, dispersion of ownership structure is popular in the United States (Berle \& Means, 1932). However, companies that exist outside of those countries are characterized by ownership concentration, with the dominant shareholding of one stockholder or group of equity holders. For instance, La Porta, Lopez-deSilanes \& Shleifer (1999) indicated that concentration ownership exist in developed states, similar for European companies, Arab countries (Egypt, Jordan, Oman and Tunisia), and East Asian companies (Becht \& Mayer, 2000; Omrana, Bolbol \& Fatheldin, 2008; Claessens, Djankov, Fan \& Lang, 2000). In the context of Palestine, Naser and Said (2009) and Ahmad (2010) showed that ownership structure is concentrated, For example, Ahmad (2010, p. 61) reported that inside ownership by managers and members of board diverge between $54 \%$ for foreign banks and $22 \%$ for national banks, while $29 \%$ of national banks are owned by families and $25 \%$ of foreign banks are owned by families.

Shleifer and Vishny (1986) argued that large stockholders may bring a positive effect to the firm's value due their role that they play in oversight management. They could exercise pressure on a corporation in order to adopt policies that alleviate private benefits of company managers. Amihud and Lev (1981) indicate that managers' works in a corporation with large stockholders are less likely to invest in non-related mergers or acquisitions (opportunistic activities). On the other hand, large shareholders obtain benefits from their control of the decisions of management (Claessens, Fan, \& Lang, 2002). Several benefits are obtained through forcing a firm to adopt policies that benefit them at the account of small shareholders, such as tunnel resource of firms to their firms, particularly when they control the firm in the form of a Pyramid structure, or adopt dividend policies that benefit them only. According to Truong and Heaney (2007), such behaviours raise a conflict between large shareholders and minority stockholders about resources of firms, which, in turn, reflects negatively on a firm's overall performance (La Porta et al., 1999).

The purpose of the current study is to investigate the effect of ownership structure on firms' performance in Palestine, just after the political and economic stability in the country (The political situation is not fully stabilized, as the country is still undergoing political turmoil, however, the beginning of the 2008 political conditions were a start to an improving political situation) (MEDPRO Report, 2011).

Many aspects differentiate this study. First, this study supplies empirical proof in line with the predictions of the agency theory with respect to ownership concentration and insider ownership from an environment that is 
different in a legal and regulatory approach from those in Western countries and the United States. Second, most extant studies in the context of Palestine focus on one aspect of ownership structure. Naser and Said (2009) examined only the effect of ownership concentration on the performance of a firm (measured by Q) .In addition, their study was conducted during a politically unstable period (2003-2006) (Intifada Al-Aqsa). However, the current study conducted in a semi-stable period (2008-2012) in order to capture the effect of ownership structure only on a firm's performance, as unstable conditions many effect the performance of a company. A studies conducted by Daraghma and Alsinawi (2010) and Ahmad (2010) examined the effect of insider ownership, board size and board composition on the performance of a firm (measured by ROA).This study, however, only examines the effect of ownership structure (ownership concentration and insider ownership). Third, most of the studies conducted in Palestine used one of measures' performance. Naser and Said (2009) used Q, Ahmad (2010) and Daraghma and Alsinawi (2010) used ROA. In contrast, this study implemented both measures ROA, and Q. The ROA shows how profitability of firm relative to its total assets, and gives an indication of how the company is able to convert the invested capital into financial revenue. In addition, ROA is considered a pointer on the performance of a company's managers and is not affected by investors' psychology (investor's acumen, and optimism or pessimism). Thus, using ROA helps to understand how ownership structure affects the performance of internal management, as it measures what a management performed in reality, away from investors' psychology.

On the other side, Demsetz and Villalonga (2001) argued that market measure (Q) is buffeted by the psychology of investors regarding to predictions of events, including the results of current firm strategies. In the case of Palestine, employing both measures may be important, because a situation that is unstable (e.g. Political conditions) may affect the perception of investors in the market for coming events, which, in turn, reflects the proper price of shares, also that information disclosure and transparency in Palestinian firms are low (Abdelkarim \& Alawneh, 2007). Several researchers have used both measures when they examined the effect of ownership structure on a firm's performance, and the results were not very different (Haniffa \& Hudaib 2006; Demsetz \& Villalonga, 2001).

\section{Literature Review and Hypotheses Development}

\subsection{Ownership Concentration}

The literature of corporate governance provides no perfect answer to the benefit and costs of concentrated ownership. Several researchers have found a positive relation with a firm's performance (La Porta, López-de-Silanes, Shleifer, \& Vishny, 2000), while others indicated a negative relationship (Loderer \& Martin, 1997). Also, some found a curvilinear relation (Morck, Shleifer, \& Vishny, 1988). Theoretically compelling arguments can be provided in support of each result.

With the positive influence of concentrated ownership in a chosen number of countries around the world, widely holding ownership is the norm. This is particularly the situation in Anglo-Saxon states, including the US and UK (La Porta et al., 1999). However, an important impairment of dispersed ownership is that it lacks both tools and incentives to treat managerial agency conflicts. In the presence of asymmetric information and unaligned interests between management and shareowners, problems linked with managerial opportunism such as a lack of effort, consuming resources, and empire building (Fama \& Jensen, 1983; Jensen \& Meckling, 1976).

In countries with dispersed ownership in which owners are usually both uninterested and incapable to perform as efficient monitors of listed corporations, other primary mechanisms become important to control and maintain firms and ensure whether their management is under control, such as markets, equity capital, and executive talent (Gillan, 2006; Walsh \& Seward, 1990).

However, in places where such a market is underdeveloped, as is often the situation of Palestine, investors do not have an option but to consent their role as monitors of a company, in which they can only practice effectively through concentrating their shareholdings. Thus, concentrated ownership gives them both stronger motives to engage in governance, as well as tools to impact on management through threat of using their rights to vote on the decisions (David, Hitt, \& Liang, 2007). Hence, concentrated stockholders can catalyze or even force the firm's managers to act in their own interests. In addition to that, in less hostile places, large stockholders can also employ their enormous wealth and previous knowledge to improve administrative and organizational abilities (Carney \& Gedajlovic, 2001). Also, existence of large shareholders wealth can assist the company in times of crisis, such as dominant stockholders opt to transmit their own wealth into an ailing company. This is also known as "propping," and can assist the corporation to survive a temporal recession in performance, when owners of firms opt "to invest private cash today in order to preserve their options to expropriate and to obtain a legitimate share of profits tomorrow" (Friedman, Johnson, \& Mitton, 2003, p. 734). 
Shleifer and Vishny (1986) examine how the ownership in the hands of dominant stockholders creates the incentives for those to observe the firm's managers, which copes with the problem of free rider linked with widely held ownership, because the minority of stockholders do not have adequate motives to bear oversight costs for the benefit of other stockholders. Due to the strong observations of large stockholders, the interests of management and shareholders are better aligned towards the aim of creating stockholder value, which results in improving the company's overall performance. The market value of a corporation with a concentrated ownership has been documented to be higher than dispersed ownership. Claessens and Djankov (1999) points out that ownership concentration to a certain degree participates in increasing a firm's value. Due to the increased ownership concentration, fewer funds are wasted in non-worthy projects. Shleifer and Vishny (1986) argued that controlling stockholders has an important role in firms because of their role in oversight management, and this may have positive effects on value of stocks. Tsionas, Andreas and Merika (2012) point out a positive relationship between concentration ownership and the performance shipping industry in the US. Lambertides and Louka (2008) indicate a positive effect for ownership structure (foreign, managerial, investment firms and government) over performance in European stock exchanges. The findings are positive for a foreign ownership only, and they argue that this is because shareholding of foreign effective corporate governance.

A negative impact of concentrated ownership though largest stockholders has the power to entice managers to manage the company in their own interests, and these interests may not align with the interests of small stockholders. The scholars of corporate governance have conventionally concentrated on the results of interest variation between management and shareowners (Fama \& Jensen, 1983; Jensen \& Meckling, 1976), but a more recent stream of scholars in corporate governance concentrates on attempts of dominant stockholders to expropriate rights of minority stockholders (Bae, Kang, \& Kim, 2002; Bertrand, Mehta, \& Mullainathan, 2002). Generally, this phenomenon is known as "tunnelling" and is usually defined as the transport of resources out of firms for the interest of their dominant stockholders (La Porta et al. 2000). There are many forms of tunnelling, including self-dealing or linked party transactions (Djankov et al., 2008). Another form may be through increasing stocks through dilutive stock issues, and dominant stockholders and managers of a company can expropriate small stockholders through setting compensation at above the market level that are unjustified by performance or efforts (Cheung, Stouraitis, \& Wong, 2005).

Haniffa and Hudaib (2006), in the context of Malaysia, indicate that holding by the five largest shareholders is related negatively with firm performance. Demsetz and Villalonga (2001), in the context of the US, point out a negative effect of that ownership concentration on performance for regulated and non-regulated. Naser and Said (2009) point out that concentration ownership has an inverse relation with performance of Palestinian firms (measured by Q) during the period of 2003-2006.

\subsection{Managerial Ownership and Firm's Performance}

Jensen and Meckling (1976) and Fama and Jensen (1983) claim that managerial ownership can create two kinds of completely differentiated behaviour; alignment of interests with stockholders and the entrenchment effect.

Jensen and Meckling (1976) argue that, as the managerial ownership increases, the propensity of managers to expend resources of a firm decreases, and thus, their interests and those of stockholders are converged. In this sense, agency conflicts between shareowners and management head for alignment of interests. They also argue that natural propensity of management to employ the resources of firms in their private interests decreased, which may not be in line with interests of outsiders of stockholders. They note that, with the increase of the manager's ownership, conflicts of interest between stockholders and management vanish due their aligned interests. However, Fama and Jensen (1983) and Demsetz (1983) indicate that significant proportion of managerial ownership beget the costs of compensation. Furthermore, they argue that, when the holding level of managers is low, the discipline of the market may encourage management to sought to value of maximization, in spite of a weak own motive to do so. On the contrary, when their stake is large and sufficient to provide them influence or voting power, they can attain their personal goals rather than the value maximization of the firm without compromising about their jobs or salaries. Maseda and Arosa (2011) found support for alignment effect in Spanish family firms (positive relation between managerial ownership and firm's performance). Haniffa and Hoodia (2006), in the context of Malaysia, and Daraghma and Alsinawi (2010) and Ahmad (2010) in the context of Palestine, found a positive relation between managerial ownership and performance of firms. Demsetz Villalonga (2001), on the sample of US firms for regulated and nonrelated firms, found a positive effect for insider ownership (managerial and directors' ownership) on performance of firm. Chena, Houb, and Lee (2012), in Taiwan, also found a positive effect for management ownership on performance (managers and directors holdings) in the hotel sector. 
The above discussion shows that an entrenchment effect is part of managerial shareholdings, which implies that too much holding of managers' ownership has a negative influence on a firm's performance. The entrenchment effect is on the grounds that concentrated shares that are in the hands of dominant stockholders create motives to exploit resources of the company for their interests at the expense of minority stockholders (Fama \& Jensen, 1983; Morck et al., 1988; Shleifer \& Vishny, 1997). The presence of these two diverse influences for managerial ownership proposes that the relation is often nonlinear between shareholdings of management and performance of firms. Different studies and investigations have dealt with hypothesis of the entrenchment, despite the results being inconclusive (Morck et al., 1988; McConnell and Servaes, 1990; Leech \& Leahy, 1994; Mudambi \& Nicosia, 1998; Faccio \& Lasfar, 1999; Lehmann \& Weigand, 2000). Chen et al. (2012), in Taiwan, found a nonlinear relation between managerial ownership and performance of firms (managers and directors holdings) in the hotel sector. Maseda and Arosa (2011) found similar relations for Spanish family firms, with insider owners between a $35 \%$ and $70 \%$ of the performance fall and the entrenchment prevails, 0 to $.35 \%$ of the alignment prevails. McConnell and Servaes $(1990,1995)$ found, in the US (they use two samples; one for 1976 and others for 1986), the effect is positive below $50 \%$ and then turns to a negative effect.

\subsection{Development of Hypotheses}

On the grounds of the former studies discussed above, the researchers test the following hypotheses to answer the question of what is the effect of ownership structure on the performance of Palestinian listed firms. Since, the ownership concentration and insider ownership direction of effects are inconclusive in light of the discussed theories, it is hypothesised as follows:

H1: There is a relation between ownership concentration and performance of Palestinian firms;

H2: There is a relation between insider ownership and performance of Palestinian firms.

\section{Design of Research}

\subsection{Sample chosen}

This study consists of all companies listed on exchange Palestine securities with data available on all ownership structure of firms and financial variables of interest from the years of 2008 to 2012. Following Demsetz and Villalonga (2001), the researchers combine regulated and non- regulated firms in their sample. This study excluded only firms that hve missed data, and this had left them with a final sample of 31 firms out of 48 . They transformed variables that have extreme values to reduce the potential effect of outliers on an estimate of coefficients (Tabachnick \& Fidell, 1996). Table 1 presents the selection measure, and Table 2 shows the distribution of sample companies according to sector classification.

Table 1. Sample chosen

\begin{tabular}{ll}
\hline Standards & N \\
\hline All firms listed on the exchange Palestine securities from 2008 to 31 December 2012. & 48 \\
firms that stopped trading at the market : & 2 \\
We excluded a Paltel Group, because it is almost monopolize a communication sector in Palestine and its share & 1 \\
represented about 33.2\% CAP of the Palestine Exchange (PEX) at the end of 2013 & \\
(http://www.paltelgroup.ps/index.php?TemplateId=1\&PageId=1\&ParentId=7\&MenuId=93\&Lang=en ) & 14 \\
firms with missed full data about their ownership structures for period of study & \\
\hline
\end{tabular}

Table 2. Sample distribution

\begin{tabular}{llll}
\hline No & sector & No. of firms & percentage \\
\hline 1 & Service & 6 & 0.193548 \\
2 & Industry & 9 & 0.290323 \\
3 & Investment & 6 & 0.193548 \\
4 & Banking financial services & 6 & 0.193548 \\
5 & Insurance & 4 & 0.129032 \\
& Total & 31 & $100 \%$ \\
\hline
\end{tabular}

\subsection{Specification of Model and Estimation}

Several studies use accounting profit to gauge performance of firms, while others use market performance or 
both. There are two aspects in which they differ. One of the aspects is a time perspective, for an accounting based is backward-looking, and for Q based is forward-looking, in trying to evaluate the impact of ownership structures on performance of firms. Measuring performance by accounting profit is constrained by accounting standards set. Market based is also constrained by investor's acumen and optimism (or pessimism). Accounting profit (ROA) is not affected by investors psychology and it only partly encompasses an estimate of the events of the future, particularly an estimation that puts on goodwill and depreciation. However, market measure (Q) is buffeted by the psychology of investors regarding predictions of events, including the results of current firm strategies (Demsetz \& Villalonga, 2001). For the used sample in this study, the researchers used both ROA, and $\mathrm{Q}$ to capture what investors allocate to a company's intangible assets (numerator in Q includes a market value of the firm).

The researchers regressed two proxies of performance on ownership elements. The first one is concentration ownership (who own more than 5\%).The second one is insider ownership (shareholding of management and director of board), and this variable had helped the researchers to understand whether managers behave with interests of shareholders by work to maximize a firm's value.

Also, the researchers include other control variables in order to isolate their effect on performance of a firm, particularly ones that are related to the performance, such as: size of firm, leverage, and membership of industry (it is acknowledged that there are factors that may affect performance that cannot be controlled, but the researchers include most of the variables that may have an effect). Regarding the size of a firm, generally, large firms have better performance due to the fact that they are able to diversify their risks (Ghosh, 1998). Moreover, large firms have more analysts monitoring their performance, and thus, they will be under pressure to work well. On the other side, small firms are more innovative, creative and alter more quickly to improve firm value (Hannan \& Freeman, 1989).

Leverage may play an important role in alleviating discretionary of managers over free cash flow and their motives to participate in less optimal activities (Jensen, 1986; Stulz, 1990). Also, debt coerces management to expend fewer perquisites to avert bankruptcy, loss of control and loss of reputation (Grossman \& Hart, 1982). Besides, contracting of debt may lead to improve managerial performance and alleviated cost of external funds (John \& Senbet, 1998). On the other hand, debt can raise conflict of interest over risk and return between debt providers and stockholders. Stiglitz and Weiss (1981) argued that, when the ratio of debt is large and shareholders have a limited liability, this may encourage the company to take risky projects in order to increase return, which would damage debt providers. The findings of empirical studies indicate contradicting results. McConnell and Servaes (1995), Short and Keasey (1999) and Weir and McKnigh (2002) all indicate a significant negative relation between leverage and performance. Hurdle (1974), however, points out that debt positively effects profitability. Daraghma and Alsinawi (2010) did not find support for debt effect on performance as an external mechanism of monitoring in the context of Palestine, which could be due to the fact that long debt is less used in the country (Harasheh \& Nijim, 2010). In addition, there is no bond market. The researchers also include industry affiliations as a control variable (a value of one if the firms belong to regulated sectors, otherwise, a value of zero), because performance of firms may rely on the sensitivity of certain sectors to alter the factors of the macroeconomy. Schmalensee (1985) indicates that industry impacts robustly affect account profit.

\subsection{Model}

$$
\begin{aligned}
& \mathrm{Q}=\alpha_{0} \pm \beta_{1} \mathrm{COW} \pm \beta_{2} \text { Insiders } \pm \beta_{3} \text { asset } \pm \beta_{4} \text { leverage } \pm \beta_{5} \text { sectots }+\varepsilon \\
& \mathrm{ROA}=\alpha_{0} \pm \beta_{1} \mathrm{COW} \pm \beta_{2} \text { Insiders } \pm \beta_{3} \text { asset } \pm \beta_{4} \text { leverage } \pm \beta_{5} \text { sectots }+\varepsilon
\end{aligned}
$$

Where Q and ROA are dependent variables (performance of firm) in models, while $\alpha_{0}$ is the constant of models. Independent variables are ownership concentration (COW) and insider. Others variables in two models are control variables, namely, size, leverage and sectors, and $\varepsilon$ - Error term.

\subsection{Variables Measurement}

The researchers, in the realm of corporate finance, have viewed a firm's performance as market value of the firm (Tobin's Q), where it reflects the value assigned by investors to a firm's assets. Demsetz and Villalonga (2001), among others, used ROA as a measure of a firm's performance, as it measures what a management achieved in reality. Daraghma and Alsinawi (2010), among others, however, have used both of them to measure the performance of a company. The researchers follow Haniffa and Hudaib (2006), who used both measures to gauge the performance of a firm. Table 3 clarifies how the proxies used were computed in this study. 
Table 3. Measurement of variables

\begin{tabular}{|c|c|c|c|}
\hline Variables & Measurement & $\begin{array}{l}\text { Expected } \\
\text { sign }\end{array}$ & Proxy \\
\hline Q & $\begin{array}{l}\text { The mean of annual values } \\
\text { For the } 5 \text { years } 2008-2012 \text {. market value of common shares } \pm \text { liabilities } \\
\text { divided by the book value of total assets of the firm. }\end{array}$ & & market measure of performance \\
\hline ROA & Profit after tax divided by total assets of the firm & & accounting measure of performance \\
\hline COW & $\begin{array}{l}\text { sum of percentage of large shareholders who own more } 5 \% \text {, then take the } \\
\text { average is of the years } 2008-2012\end{array}$ & \pm & Large stockholders \\
\hline Insider & $\begin{array}{l}\text { Sum of percentage of who own more } 2 \% \text {, then take the average of the } \\
\text { years 2008- } 2012\end{array}$ & \pm & $\begin{array}{l}\text { Ownership of managers and } \\
\text { member of directors board }\end{array}$ \\
\hline Assets & $\begin{array}{l}\text { Natural logarithm of asset at end of year. then take The average of for the } \\
\text { years 2008-2012 }\end{array}$ & \pm & Size of firms \\
\hline Leverage & $\begin{array}{l}\text { Total liabilities divide by total assets. Then take The average of the Years } \\
2008-2012\end{array}$ & $\begin{array}{l} \pm \text { or no } \\
\text { sign }\end{array}$ & $(\mathrm{D} / \mathrm{A})$ \\
\hline Sector & one if the firms belong to regulated sectors, otherwise zero & \pm & variable for sector \\
\hline
\end{tabular}

When they examine the relationship between performance of firm and ownership structure, researchers usually address this issue as a tool of governance. Demsetz and Villalonga (2001) studied this relation to examine the top five large shareholders and insider ownership of management and board directors. Also, Haniffa and Hudaib (2006), did the same. This study follows them by examining the effect of large stockholders and insider ownership on performance of firm in the context of Palestine. The researchers consider all who have more than 5\% as large stockholders in order to understand the role of large stockholders. They did not take the top five shareholders because the law of Securities in Palestine does not specify an allowable ownership level for individual investors, whether domestic or foreign (MAS 2008). This means that one owner or more can control the firm.

Also, another factor in this study they used is insider ownership. However, previous studies measure this variable as a former one (i.e., who own over 5\% and they divide between management ownership and board directors ownership) (Daraghma \& Alsinawi, 2010). The researchers address this through gathering ownership of management and board members and treat those who own more than $2 \%$ for two purposes. First, ownership of management in Palestine is very small, and if a threshold of 5\% is applied, they cannot obtain data for all firms, also taking in account that the firms listed until 2012 are 48. They obtained data for 31 firms only. In addition, previous studies argued that ownership of management helps in aligning interest between owner and manager; therefore, the researchers are interested to know whether ownership of managers helps in aligning interests of manager and owners of firms in Palestine. Despite that researchers argue that the convergence effect is at a certain point, then they may turn to the entrenchment effect, Chen et al. (2012). It is worth noting that examining the nonlinear relation between managerial ownership and the performance of a firm is out of the scope of this study. Second, the researchers combine management ownership and director's member ownership, because, in Palestine, most members of the board represent their firm's board of directors, and it is expected that they monitor behaviour of management and care greatly about wasting the firm's resources, which may reflect positively on the firm's overall performance. Also, other studies combine these two elements as one when they studied the effect of insider ownership in Malaysia (Haniffa \& Hudaib, 2006) and in the USA (Demsetz \& Villalonga, 2001).

For the expected relation between performance of a firm and elements of ownership structure, the authors do not expect a specific relation between performance and concentration of ownership, because the studies that relate to this realm are very limited in Palestine. According to Naser and Said (2009), their study was the first that addressed this issue. Also, the large stockholder could have a positive effect due to their role in monitoring management, which, in turn, reflects on using resources of the firm more efficiently. On other hand, they could exploit their power to effect on decisions of the firm so that those decisions serve their interests at the expense of small stockholders, therefore, it is expected that a relation should be positive or negative. However, for the relationship between insider ownership and a firm's performance, it is expected to be positive. Daraghma and Alsinawi (2010) found a positive relation between managerial ownership and ROA as a measure of performance of a firm, and Ahmad (2010) also found similar findings in the banking sector in Palestine. Additionally, ownership of insiders helps to align interests between managers and owners of a firm, which reduces agency problems, and managers work with interests of shareholders. For control variables, size of firm, leverage and 
membership of industry, the researchers expect firm's size to have a positive effect on performance, as large firms are capable of diversifying their risks, thus, this reflects positively on their performance (Ghosh, 1998). For leverage, they expect the relation between debt and firm's performance to be positive, negative, or have no relation. Daraghma and Alsinawi (2010) did not find the effect of debt on performance in Palestine, and Harasheh and Nijim (2010) indicate that long term debt is less used in Palestine. However, other studies outside show a positive effect due to the important role of debt in alleviating discretionary of managers over free cash flow and their motives to participate in less optimal activities (Jensen, 1986; Stulz, 1990). Also, debt coerces management to expend fewer perquisites to avert bankruptcy, loss of control and loss of reputation (Grossman \& Hart, 1982). Haniffa and Hudaib (2006), Demsetz and Villalonga (2001) and Omrana et al (2008) find effect for industry on performance of a firm, and it is expected that the relation between sector and a firm's performance to be a positive one, because performance of firms may rely on the sensitivity of certain sectors to alter the factors of the macroeconomic. This, particularly in Palestine, may be apparent for changing the political situation, and other factors that effect on sector more than others. For example, non-regulated sectors, such as the industry sectors depend on raw materials that must be imported by Israel ports, and if it prevented the imports, then the company will be prone to loss. It is true that regulated sectors, such as banks, will also be effected (provided loans will be effected, i.e., be less) by those factors but not like others. The researchers use dummy variables for sector (one if the firms belong to regulated sectors, otherwise zero).

\section{Results}

Table 4. Descriptive statistics

\begin{tabular}{lllllll}
\hline Variables & $\mathrm{N}$ & Mini & Maxi & Mean & Std. Deviation & Skewness \\
\hline (D/A) & 31 & .02 & .87 & .4035 & .23612 & .286 \\
ROA & 31 & -.03 & .09 & .0307 & .02710 & .405 \\
Q & 31 & .78 & 1.41 & .9945 & .19167 & .841 \\
COW & 31 & .10 & .58 & .3371 & .14145 & .026 \\
IN & 31 & .05 & .50 & .2381 & .11551 & .337 \\
Size & 31 & 5.52 & 9.50 & 7.717 & .91335 & .169 \\
\hline
\end{tabular}

Note. Skewness of absolute value of less than 1 is the acceptable range, according to (Hair et al., 1998).

Table 5. Correlations matrix

\begin{tabular}{llllllll}
\hline & 1 & 2 & 3 & 4 & 5 & 6 & 7 \\
\hline Q & 1 & - & $-.531^{* *}$ & $0.474^{* *}$ & .241 & $.399^{*}$ & $.395^{*}$ \\
ROA & - & 1 & $-.413^{*}$ & $.534^{* *}$ & .397 & $.386^{*}$ & $.356^{*}$ \\
COW & & 1 & & & & \\
In & & & 1 & 1 & 1 & \\
leverage \\
$\begin{array}{l}\text { asset } \\
\text { sector }\end{array}$ \\
*
\end{tabular}

Note. ${ }^{*}$ Correlation is significant at .05(2-tailed); ${ }^{* *}$ Correlation is significant at .01(2- tailed).

Table 4 shows the descriptive statistics of the variable. The average of leverage, Q, and ROA are found to be $9945 \%$, and $0307 \%$ respectively. The mean of concentration ownership (COW) is $3371 \%$, with a minimum of $10 \%$ and a maximum of 58\%. The average of insider ownership (management and member of the directors of board) is $23.81 \%$, and they own a minimum of $5 \%$ and a maximum of $50 \%$. The mean of nature log of assets is 7.7174 , with a minimum of 5.52 and a maximum of 9.50 . Table 5 shows the correlations of coefficients for all variables employed in this study. As demonstrated in Table 5, the problem of multicollinearity is not a main concern in this study. 


\subsection{Testing of Hypotheses}

Table 6. Coefficients and significant paths

\begin{tabular}{lll}
\hline Independent Variables & Unstandardized Coefficients(Dependent :Q) & Unstandardized Coefficients ( Dependent :ROA) \\
\hline Constant & $0.690^{* * *}$ & $0.42(1.045)$ \\
COW & $-.234^{* *}$ & $-.056(-1.785)^{*}$ \\
In & $.233^{*}$ & $.097(2.464)^{* *}$ \\
leverage & .078 & $.001(.303)$ \\
Asset & $.033^{*}$ & $.047(2.478)^{* *}$ \\
Sector & $.069(2.369)^{* *}$ & $.020(2.298)$ \\
$\mathrm{R}^{2}=0.386($ explained by Q) & & \\
$. \mathrm{R}^{2}=0.385($ explained by ROA) & $\mathrm{F}$ value $=4.749(\mathrm{sig})$ & F value $=4.80(\mathrm{sig})$ \\
\hline Note. &
\end{tabular}

Table 6 shows the regression findings for the influence of ownership structure on the performance of a firm. As shown in Table 6, the relation between concentration ownership (own more than 5\%) and performance in both measures (ROA and Q) is negative and significant. One explanation could be due to the lower level of information disclosure and transparency by Palestinian listed firms. In this sense, available data about firms may be not enough for investors, particular minority stockholders, which may reflect negatively on their assessment of share values. According to Abdelkarim and Alawneh (2007), ownership concentration effects the level of information disclosure and transparency by Palestinian listed firms, which, in turn, negatively affects governance practices. This implies that large shareholders in Palestine expropriate wealth of minority stockholders through controlling the decision-making processes, and direct it to serve their own interests. This may be true in the absence or weakening representation of the effect of small shareholders on board of directors, and also in the absence of protection by law for minority shareholders, where the Indicators of The Worldwide Governance (WGI) shows that the role of the law Indicator between 2008-2012 is 32\%-46\% (ranges from approximately -2.5 (weak) to 2.5 (strong)). Other Indicators are in the same range (corruption index is $-1.15 \%-78 \%$; Government Effectiveness is $32 \%-78 \%$; Regulatory Quality is $59 \%-62 \%)$ ). Furthermore, the negative relationship proposes that a firm's performance is better with more dispersed ownership structure, as argued by Pound (1988). Concentrated shares in the hands of large stockholders may result in ineffective oversight due to conflict of interests and exposure to high risk, as proposed by Demsetz and Lehn (1985). This result is in line with the prediction of the hypotheses of the entrenchment effect. Also, this may be more obvious in countries such Palestine, where the legal protection is weak for small stockholders, and in light of ability and incentive of large shareholders to exploit resources of a firm to serve their interest at the expense of minority stockholders, where the last one does not have any tool to effect the decision of a firm or stop it. Therefore, there is a significant relationship, and based on the presented argument, it found a negative relationship instead of a positive one, due to the aforementioned reasons.

In addition, a comparison of our results with former studies will make it more reasonable. The findings of the study are in line with former studies. Naser and Said (2009) point out that ownership concentration has an inverse relation with performance of Palestinian firms (measured by Q) during the period of 2003-2006. Demsetz Villalonga (2001) found a negative relation between five large shareholdings and US firms performance (measured by Q). Haniffa and Hudaib (2006), in the context of Malaysia, point out that a large of stockholders are related negatively with market performance, but there is a positive relation between shareholdings of the top five shareholders and performance of firms (ROA). This positive relation (based on accounting performance) is opposite to results of market performance, meaning that concentrated shares in the hands of the top five stockholders render important motives for convergence between managers' interests and stockholders in Malaysia, leading to a firm's good performance, as suggested by (Li \& Simerly, 1998).

However, the findings of the current study are inconsistent with Shleifer and Vishny (1986), Tsionas el at (2012), and Lambertides and Louka (2008). Tsionas et al. (2012) points out that the relationship between concentration ownership and performance is positive in the shipping industry. Also, Omrana et al. (2008) found a positive effect for ownership concentration on market performance for four Arab countries (Egypt, Jordan, Oman and Tunisia.). Pathirawasam and Wickremasinghe (2012) found no significant relation between ownership concentration and performance (ROA) in Colombo. Also, Omrana et al. (2008) found no significant relation between ownership concentration and performance (ROA and ROE). 
For another factor of ownership, the findings indicate that insider ownership has a positive significant relation with both measures (ROA and Q) of a firm's performance. This is in line with prediction of alignment hypothesis, Jensen and Meckling (1976) and Fama and Jensen (1983), who imply that shareholding of insiders (management and members of board directors) helps to align interests between shareholders and managers, which reflect on their behaviour in running the firm so that they follow maximization of the firm's value (e.g., follow less risky strategies, investing in projects that have a positive net present value, and lead to an increase in performance, as less resources are wasted) rather their own interest. Also, a positive relation between insiders ownership and performance of a firm could be considered as a suitable tool of corporate governance in the context of Palestine, where shareholding by insiders who seem to grasp the nature of business better, are familiar with internal policies, have good knowledge and appreciation of the running of the firm, which enables them to make decisions that are in the interest of maximizing the firm's value, and their position enable them to doing so, rather than engaging in opportunistic behaviour, as the benefits from the decisions, in addition to stockholders. Also, shareholding by insiders may be considered an incentive for them to increase the firm efficiency, which eventually leads to reduce the conflicts between management and owners of firms about using resources. Ahmad (2010) reported that, in the banking sector in Palestine, increasing inside ownership by $1 \%$ causes an increase the ROA by $4.76 \%$. Bahgat and Bolton $(2006$, p. 7$)$ indicated that an independent board or members of the board with appropriate shares will have a motive to make effective oversight on important firm decisions, thus the "board independence or ownership can be a good proxy for overall good governance". In Palestine, board members mostly represent their firms on board. Accordingly, they performed good monitoring for managers decisions, as proper decisions will effect directly on their stakes.

In addition to that, current results agree with several previous studies, and contradict with others. Ahmad (2010, p. 69) found that managerial ownership has a significant positive relationship with the performance of banks in Palestine, and the results are also consistent with the findings of Daraghma and Alsinawi (2010), which indicate that managerial ownership positively affects the performance of firms in Palestine. Demsetz and Villalonga (2001) found a positive relation for managerial ownership and performance of firms on a sample of US firms, for both regulated and non-regulated firms. Chena et al. (2012) found, in Taiwan, a positive effect for management ownership on performance (managers and directors holdings) in the hotel sector. Maseda and Arosa (2011) found support for alignment effects in Spanish family firms. However, the results contradict with Haniffa and Hudaib (2006) in the Malaysian context, which find no significant relation between insider ownership and market performance. Their findings claim that accounting performance is negative, which is inconsistent with the results of this study. Haniffa and Hudaib (2006) argued that shareholding of managers is unsuitable as a tool of corporate governance in Malaysian context, because managers follow more risky strategies that maximize their personal interest rather than stockholders' interest. This leads to lower results of accounting performance, as proposed by Himmelberg et al. (1999).

For control variables, the results show that size of firm is positively related $(\mathrm{p}<0.1)$ with performance. This implies that, when a company becomes large, its capability to produce returns improves. This results with the prediction of the theory of micro economic of economics to scale. Moreover, the findings agree with Ghosh, (1998), Chhibber and Majumder (1999), Kuntluru, Muppani, and Khan (2008), Omrana et al. (2008) and Pathirawasam and Wickremasinghe (2012). The leverage is found to have no significant relation with market performance. It is worth noting that long-run debt is less used in Palestine (Harasheh \& Nijim, 2010). In addition, there is no bond market (Daraghma \& Alsinawi 2010). Also, Daraghma and Alsinawi (2010) found no effect of debt on performance in Palestine, implying that debt is an external mechanism of monitoring and is ineffective in the context of Palestine. The results are inconsistent with Haniffa and Hudaib (2006), who found that gearing has a positive effect with market performance. The variable of sectors were found to have a significant $(\mathrm{p}<0.05)$ relationship with market performance, and this in line with the industrial effect hypothesis (Schmalensee, 1985). This implies that, in Palestine, regulated firms performed better than unregulated firms. Haniffa and Hudaib (2006) indicate that the trading sector performs better than the industrial sector. Demsetz Villalonga (2001) found a different relation between sectors and market performance, and indicates that media sectors are positively related with the performance, and with financial sectors negatively. Omrana et al. (2008) found, in four Arab countries, that sectors have a significant relation with performance (negative for financial sector and positive for manufacturing).

\section{Summary and Conclusion}

This work further empirically investigates the relation between ownership structure and performance of a firm. Extant studies by Daraghma and Alsinawi (2010) and Ahmad (2010), found that managerial ownership significantly and positively affects a firm's performance, and Naser and Said (2009) found concentration 
ownership to significantly impact the performance of a company, and motivates this work. The results of this work have useful and practical implications. The results are beneficial for investors, particular individuals who do not have sufficient knowledge or resources to conduct a study to evaluate a firm, where they use nature of ownership structure of a firm as an one of the indications to evaluate the firm's performance, as the concentrated ownership has a negative effect on the performance. According to Abdelkarim \& Alawneh (2007), the level of information disclosure and transparency is low in Palestinian listed firms, and it affects negatively governance practices, while the ownership of insiders has a positive effect on performance of a firm through aligned interests between managers and shareholders for firms in Palestine. It may beneficial to promote ownerships of insiders (management and members of board), as it has a positive effect on its performance. Researchers argued that this may convert from alignment effect to entrenchment effect at a certain point of shareholding of insiders, because they are able to control a firm's decision, and, at this time, they may follow their own interest rather than firm value maximization, and try to reduce concentration of their ownership structure, which, in turn, may send messages to the minority that its right will not expropriate by majority in light of weak protection law for minority rights in Palestine. As a result, confidence of investors increases, which reflects on a lower cost of capital. Based on the above, the results of the current study propose that the future policy makers and authorities in Palestine should ensure more minority shareholders' rights through issuing or modifying regulations, such as a limited ownership of an individual firm to prevent someone or some group from controlling the firm, as current the law of Securities does not specify the allowable ownership level for an individual investor, whether domestic or foreign (MAS, 2008). As such, an action may enhance an effective corporate governance system, whether within an individual company, or across an economy as a whole (Abdelkarim \& Alawneh, 2007) (that ownership concentration effect on information disclosure and transparency, and that have a negative effect on governance), thus encouraging investors to provide capital for firms, as good corporate governance ensures to employ resources more efficiently. Consequently, this supports economy growth. Also, taking into account that Palestine is under established, and the equity market is considered an important source for financing firms in order to expand their activities, which helps to advance the country and create more jobs. Also, in Palestine, a bonds market is not available. This task is not easy because legal protection of investors is low, and in light of ownership concentration (La Porta et al., 2000).

\section{Limitations of Study}

The findings of the current study may be subject to many limitations that could be suggestions for future studies. First, because of the unavailability of data about institutional investors, and the nature of investors, whether local, foreign or family, only two variable of ownership structures were considered in this study. Thus, future researches may want to consider other components of ownership structure variables, such as institutional ownership and kinds of those institutions. If future studies have access to this information to test the effect of elements of ownership on the performance of a firm, where they are expected to have a role in monitoring managers (institutional ownership has ability and incentive to monitor management due to their shareholding), which may have a positive effect on performance. Foreign investors could also bring some experience (monitor management) from their country, which positively contributes to a firm's performance.

Second, this study used OLS regression to examine the relation between ownership structure and performance. Therefore, future studies may use 2 OLS regression models (instrument variable) in order to address the endogeneity issue (i.e., relation between managerial ownership and performance), as suggested by the literature. Managerial ownership may be affected by performance, because managers are able to access to information and modify their ownership according to performance, and, at the same time, their ownership affects the performance of firms.

Finally, a simultaneous equations framework to test the non-directional relation between managerial ownership and a firm's performance was used (Agrawal \& Knoeber, 1996). The role of managerial ownership turns after a certain point from an alignment effect to an entrenchment effect. Thus, future studies may use different cut-point off to test the effect of managerial ownership on performance.

\section{References}

Ahmad, A. (2010). How does corporate governance affect performance of banks in Palestine? Master of Business Administration. As part of the degree, School of Management. University of Bath.

Amihud, Y., \& Lev, B. (1981). Risk reduction as a managerial motive for conglomerate mergers. Bell Journal of Economics, 12, 605-617. http://dx.doi.org/10.2307/3003575

Bae, K. H., Kang, J. K., \& Kim, J. M. (2002). Tunnelling or value added? Evidence from mergers by Korean business group. Journal of Finance, 57, 2695-2740. http://dx.doi.org/10.1111/1540-6261.00510 
Berle, A., \& Means, G. (1932). The Modern Corporation and Private Property. Harcourt, Brace, \& World, New York.

Bertrand, M., Mehta, P., \& Mullainathan, S. (2002). Ferreting out tunnelling: An application to Indian business groups. Quarterly Journal of Economics, 117, 121-148. http://dx.doi.org/10.1162/003355302753399463

Carney, M., \& Gedajlovic, E. R. (2001). Corporate governance and firm capabilities: A comparison of managerial, alliance, and personal capitalisms. Asia Pacific Journal of Management, 18, 335-354. http://dx.doi.org/10.1023/A:1010649828352

Chhibber, P. K., \& Majumdar, K. K. (1999). Foreign ownership and profitability: property rights, control and the performance of firms in Indian Industry. Journal of Law and Economics, 42, 209-238. http://dx.doi.org/10.1086/467423

Claessens, S., \& Djankov, S. (1999). Ownership Concentration and Corporate Performancein the Czech Republic. Journal of Comparative Economics, 27, 498-513. http://dx.doi.org/10.1006/jcec.1999.1598

Claessens, S., Djankov, S., Fan, J. P. H., \& Lang, L. H. P. (2000). Expropriation of Minority Shareholders in East Asia. CEI Working Paper Series 2000-4, Center for Economic Institutions, Institute of Economic Research, Hitotsubashi University.

Claessens, S., Djankov, S., Fan, J., \& Lang, L. (2000). The separation of ownership and control in East Asian $\begin{array}{lllll}\text { corporations. Journal of Financial } & \text { Economics, }\end{array}$ http://dx.doi.org/10.1016/S0304-405X(00)00067-2

Claessens, S., Fan, J. P. H., \& Lang, L. H. P. (2002). The Benefits and Costs of Group Affiliation: Evidence from East Asia. Working Paper Series UNU-WIDER Research Paper. World Institute for Development Economic Research (UNU-WIDER). http://dx.doi.org/10.1596/1813-9450-2924

Daraghma, M. A., \& Alsinawi, A. A. (2010). Board of Directors, Management Ownership, and Capital Structure and Its Effect on Performance: The Case of Palestine Securities Exchange. International Journal of Business and Management, 5(11), 118. http://dx.doi.org/10.5539/ijbm.v5n11p118

David, P., Hitt, M. A., \& Liang, T. W. (2007). The benefits and costs of large block ownership before and during the East-Asian crisis (working paper).

Demsetz, H., \& Lehn, K. (1985). The structure of corporate ownership: causes and consequences. Journal of Political Economy, 93, 1155-1177. http://dx.doi.org/10.1086/261354

Demsetz, H., \& Villalonga, B. (2001). Ownership structure and corporate, performance. Journal of Corporate Finance, 7(3), 209-233. http://dx.doi.org/10.1016/S0929-1199(01)00020-7

Djankov, S., La Porta, R., López-de-Silanes, F., \& Shleifer, A. (2008). The law and economics of self-dealing. Journal of Financial Economics. http://dx.doi.org/10.1016/j.jfineco.2007.02.007

Faccio, M. M., \& Lasfer. (1999). Managerial Ownership, Board structure \& Firm Value: The UK Evidence. City University Working Paper.

Fama, E. F., \& Jensen M. C. (1983). Separation of Ownership and Control. Journal of Law and Economics, 26, 301-25. http://dx.doi.org/10.1086/467037

Friedman, E., Johnson, S., \& Mitton, T. (2003). Propping and tunneling. Journal of Comparative Economics, 31, 732-750. http://dx.doi.org/10.1016/j.jce.2003.08.004

Gedajlovic, E., \& Shapiro. D. (1998). Management and Ownership Effects: Evidence from Five Countries. Strategic Management Journal, 19, 533-553. http://dx.doi.org/10.1002/(SICI)1097-0266(199806)19:6<533::AID-SMJ957>3.0.CO;2-\#

Ghosh, A. (1998). Does Accounting Base Performance Really Improve Following Corporate Acquisitions? Working Paper (Zickling School of Business, Baruch College (CUNY), New York, USA).

Gillan, S. L. (2006). Recent developments in corporate governance: An overview. Journal of Corporate Finance, 12, 381-402. http://dx.doi.org/10.1016/j.jcorpfin.2005.11.002

Grossman, S., \& Hart, O. (1982). Corporate Financial Structure and Managerial Incentives. University of Chicago Press.

Hair, J. F., Anderson, R. E., Tatham, R. L., \& Black, W. C. (1998). Multivariate Data Analysis with readings. Prentice-Hall, Englewood Cliffs, NJ. 
Haniffa, R., \& Hudaib, M. (2006). Corporate Governance Structure and Performance of Malaysian Listed Companies. Journal of Business Finance \& Accounting, 33(7\&8), 1034-1062. http://dx.doi.org/10.1111/j.1468-5957.2006.00594.x

Himmelberg, C. P., Hubbard, R. G., \& Palia, D. (1999). Understanding the Determinants of Managerial Ownership and the Link between Ownership and Performance. Journal of Financial Economics, 53, 353-384. http://dx.doi.org/10.1016/S0304-405X(99)00025-2

Hurdle, G. (1974). Leverage, Risk, Market Structure and Profitability. Review of Economics and Statistics, 56, 478-85. http://dx.doi.org/10.2307/1924463

Jensen, M. C. (1986). The Agency Costs of Free Cash Flow. American Economic Review-Papers and Proceedings, 76, 326-329.

Jensen, M. C., \& Meckling, W. H. (1976). Theory of the firm: managerial behavior, agency costs and ownership $\begin{array}{lllll}\text { structure. Journal of } & \text { Financial 305-360. }\end{array}$ http://dx.doi.org/10.1016/0304-405X(76)90026-X

Joh, S. W. (2003). Corporate Governance and Firm Profitability: Evidence from Korea before the Economic Crisis. Journal of Financial Economics, 68, 287-322. http://dx.doi.org/10.1016/S0304-405X(03)00068-0

John, K., \& Senbet, L. (1998). Corporate Governance and Board Effectiveness. Journal of Banking and Finance, 22, 371-404. http://dx.doi.org/10.1016/S0378-4266(98)00005-3

Kuntluru, S., Muppani, V. R., \& Ali Khan, M. A. (2008). Financial performance of foreign and domestic owned companies in India. Journal of Asia-Pacific Business, 9, 28-54. http://dx.doi.org/10.1080/10599230801971259

La Porta, R., Lopez-de-Silanes, F., Shleifer, A., \& Vishny, R. (1997). Legal determinants of external finance. Journal of Finance, 52, 1131-1150. http://dx.doi.org/10.1111/j.1540-6261.1997.tb02727.x

La Porta, R., Lopez-de-Silanes, F., Shleifer, A., \& Vishny, R. (1998). Law and finance. Journal of Political Economy, 106(6), 1113-1155. http://dx.doi.org/10.1086/250042

La Porta, R., Lopez-de-Silanes, F., Shleifer, A., \& Vishny, R. (1999). Corporate ownership around the world. Journal of Finance, 54, 471-517. http://dx.doi.org/10.1111/0022-1082.00115

La Porta, R., Lopez-de-Silanes, F., Shleifer, A., \& Vishny, R. (2000). Investor protection corporate governance. Journal of Financial Economics, 58, 3-27. http://dx.doi.org/10.1016/S0304-405X(00)00065-9

Lambertides, N., \& Louka, C., (2008). Ownership structure and operating performance: evidence from the European maritime industry. Maritime Policy and Management, 35(4), 395-409. http://dx.doi.org/10.1080/03088830802198308

Leech, D., \& Leahy, J. (1991). Ownership structure, control type classifications and the performance of large British companies. Economic Journal, 101, 1418-1437. http://dx.doi.org/10.2307/2234893

Lehmann, E., \& Weigand, J. (2000). Does the Governed Corporation Perform Better? European Finance Review, 4, 157-195. http://dx.doi.org/10.1023/A:1009896709767

Li, M., \& Simerly, R. (1998). The Moderating Effect of Environmental Dynamism on Ownership and $\begin{array}{llll}\text { Performance Relationship. Strategic Management Journal, 19, 169-179. } & \text { 19, }\end{array}$ http://dx.doi.org/10.1002/(SICI)1097-0266(199802)19:2<169::AID-SMJ939>3.0.CO;2-2

Loderer, C., \& Martin, K. (1997). Executive stock ownership and performance: tracking faint traces. Journal of Financial Economics, 45, 223-255. http://dx.doi.org/10.1016/S0304-405X(97)00017-2

McConnell, J. J., \& Servaes, H. (1995). Equity ownership and the two facets of debt. Journal of Financial Economic, 39, 131-157. http://dx.doi.org/10.1016/0304-405X(95)00824-X

MEDPRO. (2011). Israel and Palestine and state (un)sustainability Paolo Napolitano. Retrieved from http://www.medpro-foresight.eu

Morck, R., Shleifer, A., \& Vishny, R. W. (1988). Management ownership and market valuation: an empirical $\begin{array}{llll}\text { analysis. Journal of Financial 20 Economics, } & \text { 20(1/2), }\end{array}$ http://dx.doi.org/10.1016/0304-405X(88)90048-7

Mudambi, R., \& Nicosia, C. (1998). Ownership structure and firm performance: evidence from the UK financial services industry. Applied Financial Economics, Taylor \& Francis Journals, 8(2), 175-180. http://dx.doi.org/10.1080/096031098333159 
Murad, H., Harasheh, M. H., \& Nijim, M. (2010). The impact of institutional investors of the performance of companies listed at the PSE. Journal of Business Policy Research, 5(1), 28-40.

Naser, A., \& Said, A. (2009). The relationship between corporate governance and the performance of Palestinian firms: An empirical study. International Journal of Business \& Finance Research (IJBFR), 3(2), 105-120.

Omrana, M. M, Bolbol, A., \& Fatheldin, A. (2008). Corporate governance and firm performance in Arab equity markets: Does ownership concentration matter? International Review of Law and Economics, 28, 32-45. http://dx.doi.org/10.1016/j.irle.2007.12.001

Pathirawasam, C., G., \& Wickremasinghe, G. (2012). Ownership concentration and financial performance: The case of SRI LANKAN listed companies. Corporate Ownership \& Control, 9(4).

Qubbaja, A., Hamid, M., \& Shikaki, I. (2008). Enhanciing Corporate Governance in Pallestiine. Palestine Economic Policy Research Institute (MAS). Retrieved from http://www.pal-econ.org

Schmalensee, R. (1985). Do Markets Differ Much? American Economic Review, 75, 341-351.

Shleifer, A., \& Vishny, M. W. (1986). Large Shareholders and Corporate Control. Journal of Political Economy, 94, 461-88. http://dx.doi.org/10.1086/261385

Stiglitz, J., \& Weiss, A. (1981). Credit Rationing in Markets with Imperfect Information. American Economic Review, 71, 393-410.

Stulz, R. (1990). Managerial Discretion \& Optimal Financing Policies. Journal of Financial Economics, 26, 3-27. http://dx.doi.org/10.1016/0304-405X(90)90011-N

Truong, T., \& Heaney, R. (2007). Largest shareholder and dividend policy around the world. Quarterly Review of Economics and Finance, 47(5), 667-668

Tsionas M. G., Andreas, G., Merikas, A. G., \& Merika, A. A. (2012). Concentrated ownership and corporate performance revisited: The case of shipping. Transportation Research Part E, 48, 843-852. http://dx.doi.org/10.1016/j.tre.2012.01.004

Walsh, J. P., \& Seward, J. K. (1990). On the efficiency of internal and external corporate control mechanisms. Academy of Management Review, 15, 421-458.

Weir, C., \& McKnigh, P. (2002). Internal and External Governance Mechanisms: Their Impact on the Performance of Large UK Public Companies. Journal of Business Finance \& Accounting, 29, 579-611. http://dx.doi.org/10.1111/1468-5957.00444

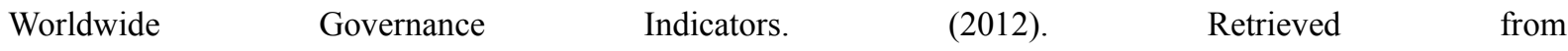
http://info.worldbank.org/governance/wgi/index.aspx\#reports

\section{Copyrights}

Copyright for this article is retained by the author(s), with first publication rights granted to the journal.

This is an open-access article distributed under the terms and conditions of the Creative Commons Attribution license (http://creativecommons.org/licenses/by/3.0/). 